\title{
Remarkable invasion of San Francisco Bay (California, USA) by the Asian clam Potamocorbula amurensis. I. Introduction and dispersal
}

\author{
James T. Carlton ${ }^{1}$, Janet K. Thompson ${ }^{2}$, Laurence E. Schemel ${ }^{2}$, Frederic H. Nichols ${ }^{2}$ \\ ${ }^{1}$ Maritime Studies Program, Williams College - Mystic Seaport, Mystic, Connecticut 06355, USA \\ ${ }^{2}$ Water Resources Division, U.S. Geological Survey, 345 Middlefield Road (MS-496), Menlo Park, California 94025, USA
}

\begin{abstract}
The euryhaline bivalve mollusc Potamocorbula amurensis (family Corbulidae), a native of China, Japan, and Korea, has recently appeared and become very abundant in San Francisco Bay. This clam appears to have been introduced as veliger larvae in the seawater ballast of cargo vessels. It was first collected in northern San Francisco Bay in late 1986. P. amurensis then spread throughout the estuary within $2 \mathrm{yr}$ and reached densities at some sites exceeding $10000 \mathrm{~m}^{-2}$ It lives primarily in the subtidal on all substrates (mud, sand, peat, and clay) and is found in the full range of bay salinities $(<1$ to $33 \%$ ). Its explosive increase in abundance and spread may result in major alterations of the San Francisco Bay estuary ecosystem. These could include changes in (1) trophic dynamics (through competition with other suspension-feeding and deposit-feeding infauna; changes in benthic community energy flow; availability of a new and abundant prey item for birds, fish, and crabs; and reduction - as a result of its filter feeding - of phytoplankton standing stock) and (2) benthic dynamics (through inhibition and/or enhancement of infauna due to substrate destabilization; alteration of suspended sediment load of near-bottom water; and change of sediment surface redox balance). The early detection of the appearance and spread of $P$. amurensis in San Francisco Bay makes this one of the best documented invasions of any estuary in the world.
\end{abstract}

\section{INTRODUCTION}

The movement of shallow-water, often estuarine, organisms across ocean basins and over continents as a consequence of human activities continues to be a major mechanism mediating biological invasions in the sea (Carlton 1989). Carlton (1987) predicted that the bays and estuaries of the Pacific coast of North America would continue to be receptive to new invasions from elsewhere in the Pacific Basin. In the 1980s these invasions largely resulted from the release of seawater ballast from cargo vessels (Carlton 1985, Williams et al. 1988).

One such remarkable invasion is now occurring in San Francisco Bay, California. In 1987 several workers recognized that a small unknown bivalve mollusk, first collected in late 1986, had not been recorded previously from the bay. Its apparently sudden appearance and subsequent increase and spread prompted speculation that this clam had been recently introduced. The clams were subsequently identified as a member of the Corbulidae, a bivalve family not previously known from the bay. Based upon an initial identification by $\mathrm{A}$. Matsukuma (National Science Museum, Tokyo), and upon the descriptions and figures of Schrenck (1867), Zhadin (1952), and Zhuang \& Cai (1983), the San Francisco Bay clams are the Asian species Potamocorbula amurensis (Schrenck, 1867) (Fig. 1). We have chosen to use the name 'amurensis' pending a revision of the large number of specific names in this group now being undertaken by Dr Matsukuma. A brief description of the San Francisco Bay specimens, and discussion of Potamocorbula species-level taxonomy, are included in the Appendix.

We report here the establishment in San Francisco Bay of Potamocorbula amurensis, and its increase in numbers and spread between 1986 and 1988. We consider evidence for the mechanism and timing of its transoceanic dispersal from the Western Pacific Ocean to the Eastern Pacific Ocean. Finally, we speculate 

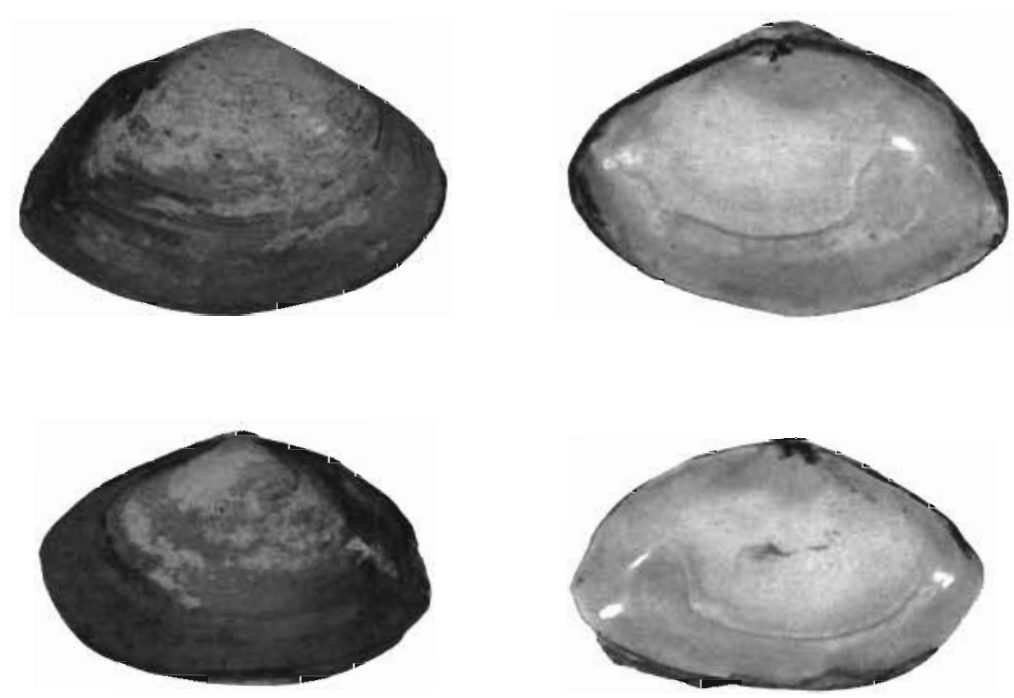

Fig. 1 Potamocorbula amurensis (Schrenck) ( $x$ 2.5) from San Francisco Bay, California, USA. External and internal views of right valve (upper row) and left valve (lower row)

briefly about the possible effects this clam may have on the benthic and planktonic communities of San Francisco Bay.

\section{DISCOVERY AND SPREAD OF POTAMOCORBULA AMURENSIS IN SAN FRANCISCO BAY}

\section{Methods}

The occurrence of Potamocorbula amurensis in San Francisco Bay is documented from a number of ongoing sampling programs. Details of sampling sites, dates, frequencies, and protocols of these programs are given in Table 1. The major collections were those of the Regional Effects Monitoring (REM) program, a cooperative program of the California State Water Quality Control Board and the United States Geological Survey (USGS). Additional collections were made by the California Department of Water Resources (DWR), the National Oceanic and Atmospheric Administration (NOAA), and Diablo Valley Community College (DVC) (Table 1), REM samples were collected in all major bay regions (Fig. 2) at ca 2 mo intervals from March 1987 until November 1988. These regions are described in detail by Nichols \& Pamatmat (1988). The recognition of a previously unidentified clam in bay benthic samples led to retrospective searches by us of earlier REM and NOAA samples, by DVC of their samples, and by Hydrozoology, Inc. of DWR samples.

\section{Results}

The initial distribution and increasing abundances of Potamocorbula amurensis from October 1986 to December 1987 are shown in Fig. 3. Densities at 3 north bay locations from March 1987 to November 1988 are shown in Fig. 4. Population sizes given below are reported as means with standard deviations.

The first 3 specimens of Potamocorbula amurensis found in San Francisco Bay were collected in October 1986 (DVC) in Grizzly Bay. Two specimens were collected $1.8 \mathrm{~km}$ south of the REM/DWR Grizzly Bay stations; a third specimen was collected on the south shore of Suisun Bay (Figs. 2 and 3a) (W. Stephenson pers. comm. 1988). Earlier collections (April and July 1986, DVC) contained no $P$. amurensis. A combined total of about 134 samples were collected by these programs (REM, DWR, DVC) in Grizzly and Suisun Bays from September to December 1986, but only DVC samples contained $P$. amurensis.

Potamocorbula amurensis was next seen in quantitative samples in January 1987 (Fig. 3b). Three specimens (one per grab in 3 replicates) were collected in January (USGS) at a San Pablo Bay station (at a site not subsequently chosen for further sampling) where no individuals had been found in samples taken $4 \mathrm{mo}$ earlier These were the first specimens collected west of Carquinez Strait. Sampling at 3 closely spaced stations at a subtidal location $5.4 \mathrm{~km}$ east of this location sampled 1 wk later in January (NOAA) yielded a total. of $174 P$. amurensis in 14 of the 15 samples collected at the 3 stations. Samples from Grizzly Bay collected at the end of February 1987 (DWR) included only one specimen in 3 replicates.

Thus by March 1987 (Fig. 3b) only a few specimens had been collected at various sites in the North Bay region. It would appear unlikely that the clam was abundant in the bay prior to the spring of 1987 . Regular baywide sampling, commenced by REM in March 1987 at 8 stations (Table 2), provide the core of our understanding of the increase in abundance and spread of Potamocorbula amurensis. We divide our discussion of its subsequent history into its occurrences in the North 
Table 1. Selected sampling programs relative to the occurrence of Potamocorbula amurensis in San Francisco Bay

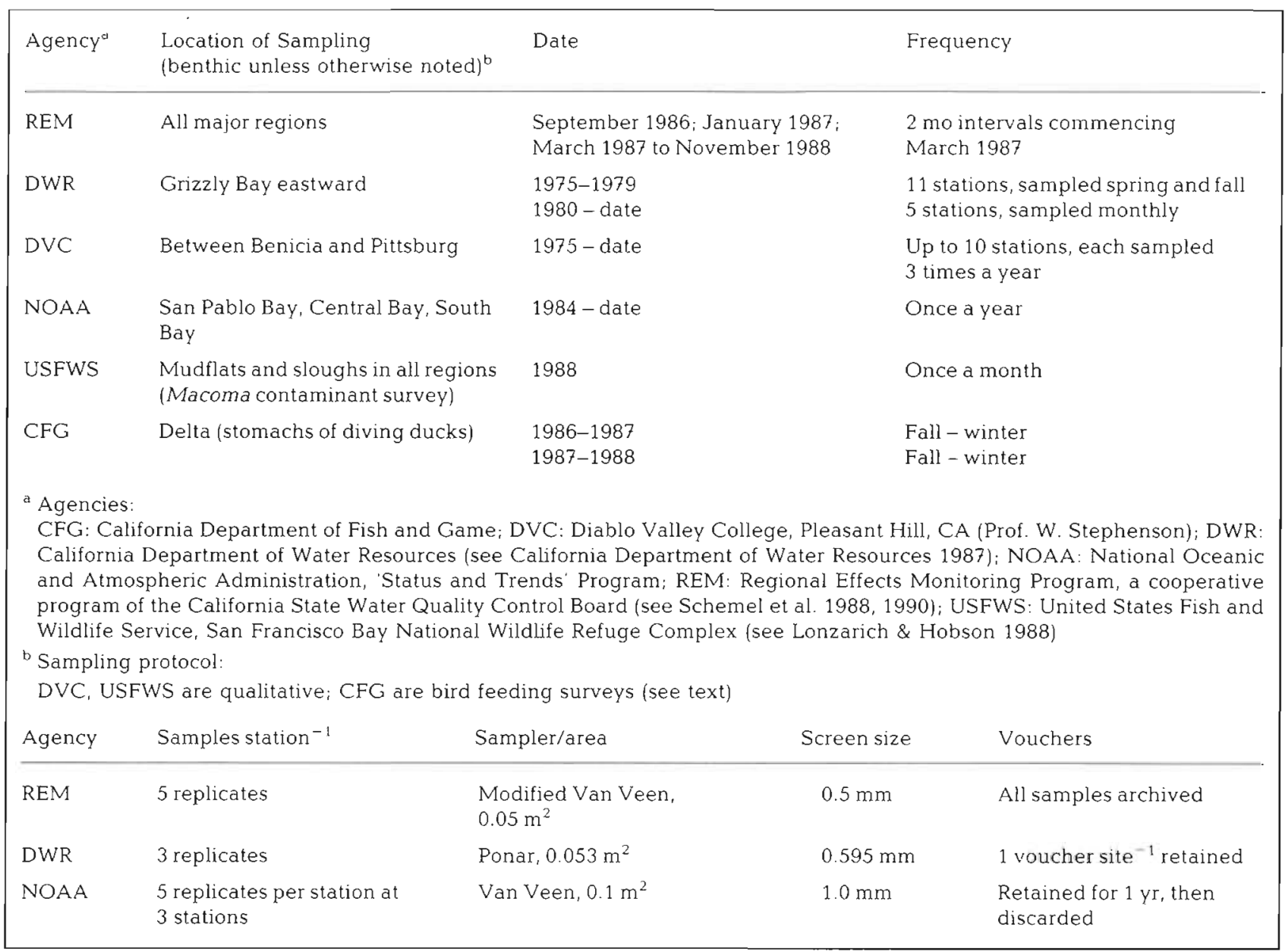

Bay, Central Bay, and South Bay, the major bay regions delineated by the REM program (Schemel et al. 1988).

\section{North Bay}

A few specimens of Potamocorbula amurensis were first seen, as noted above, in Grizzly and Suisun Bays in October 1986. By late spring 1987 the species was well established from San Pablo Bay through Suisun Bay (Fig. 3b, c). P. amurensis first appeared (in numbers greater than 20 ind. $0.05 \mathrm{~m}^{-2}$ ) upriver of Suisun Bay in June 1987 at Point Sacramento, a DWR station (Figs. 2 and 3c) where densities reached a maximum (as of December 1988) of 330 ( \pm 178 ind. $0.05 \mathrm{~m}^{-2}$ in September 1987 . This station is located $2.7 \mathrm{~km}$ above the confluence of the Sacramento and San Joaquin Rivers.

At the Sherman Lake site, located in a shallow flooded region between the Sacramento and San Joaquin Rivers, Potamocorbula amurensis appeared between July 1987 and December 1988, never exceed- ing mean densities of $6( \pm 3)$ ind. $0.05 \mathrm{~m}^{-2}$. In samples from another USGS program (Nichols et al. unpubl.) occasional individuals were found to occur as far upriver as Rio Vista (Fig. 2), where salinities average $<1 \%$ throughout much of the year.

A time course of Potamocorbula amurensis abundance in Grizzly Bay (Fig. 4) shows a rapid increase at this site in June 1987 with most individuals being very small (average size $1.7 \mathrm{~mm}$ ). A similar increase in abundance was seen in spring 1988 (and maintained through early fall) at the shallow water San Pablo Bay station (Fig. 4). The data at these 2 stations suggest a spring recruitment. As might be expected following such large sets (>10000 ind. $\left.\mathrm{m}^{-2}\right)$, densities fell off dramatically with population aging during the remainder of the year (Fig. 4). This phenomenon is in concert with our knowledge of a related Chinese Potamocorbula species (see 'Distributional ecology and biology', below). However, $P$. amurensis at the deeper San Pablo Bay station (Fig. 4) reached peak densities in fall of 1987, dropping off thereafter. These conflicting abun- 


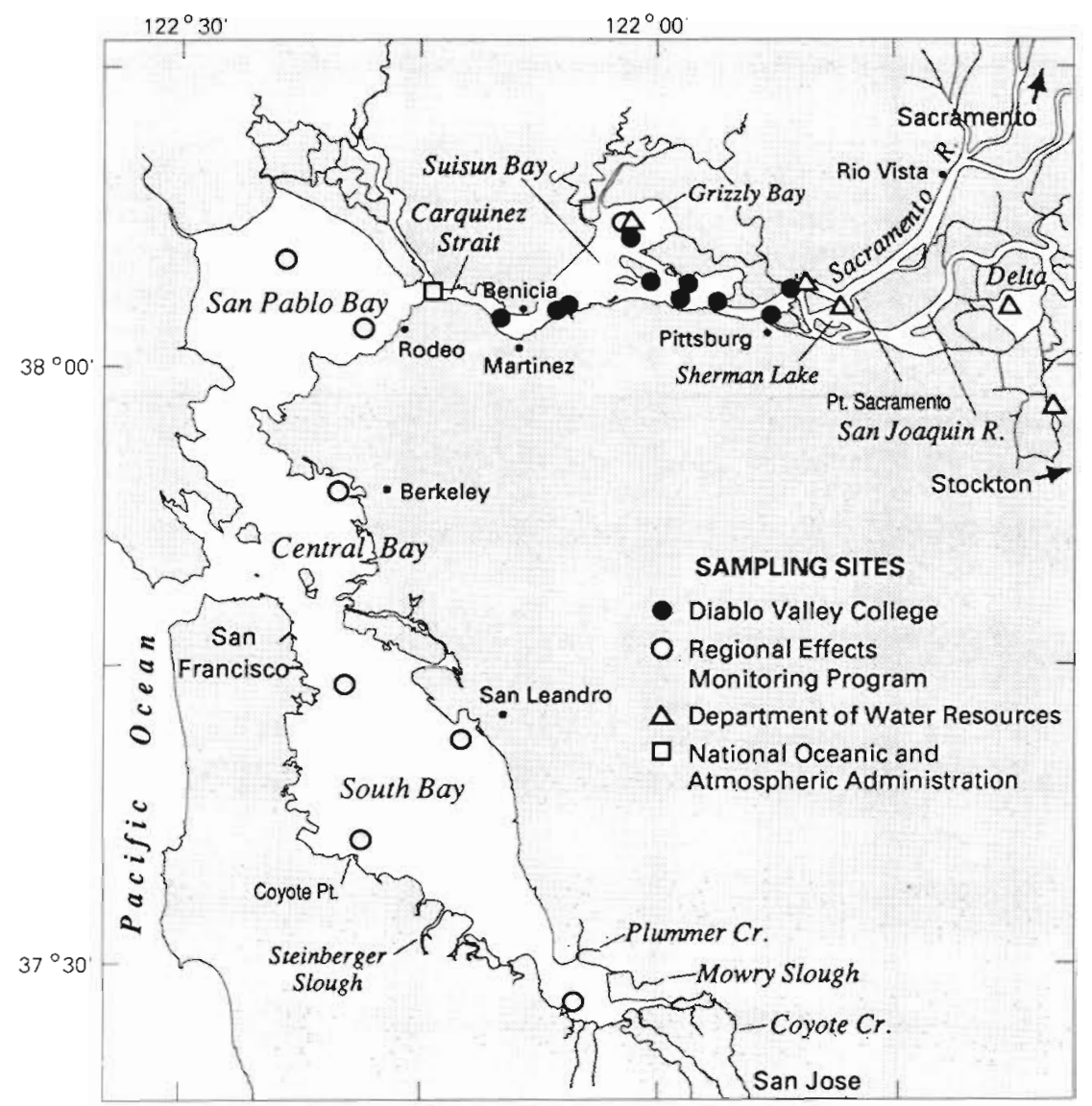

Fig. 2. San Francisco Bay. Selected sampling stations shown (see Table 1), and other localities referred to in text dance patterns suggest a complex picture of patchy recruitment in space and time, as might be expected for an invasive eurytopic species.

Since May 1987 Potamocorbula amurensis has been the most abundant benthic macroinfaunal organism in Grizzly Bay, generally occurring in numbers 10 times or greater than those of any other species (Nichols et al. $1990)$.

\section{Central Bay}

Potamocorbula amurensis was recorded rarely at the single Central Bay station off Berkeley (Table 2, Fig. 2). Three specimens in one replicate were collected in June 1987; none were collected thereafter until January 1988. From January until November 1988 numbers did not exceed $2.0( \pm 1.0)$ ind $0.05 \mathrm{~m}^{-2}$

\section{South Bay}

Potamocorbula amurensis first appeared in South San Francisco Bay in June 1987 at the Coyote Point site ( 1 and 2 specimens in 2 of 5 replicates) and Palo Alto (1 specimen in 1 of 5 replicates) (Table 2, Fig. 2). It appeared thereafter consistently in low densities at
Coyote Point, where numbers increased from about 2.0 $( \pm 2.0)$ ind $0.05 \mathrm{~m}^{-2}$ in summer 1988 to $43( \pm 12.0)$ ind. $0.05 \mathrm{~m}^{-2}$ in fall 1988. P. amurensis was represented at Palo Alto throughout the REM survey by only a few specimens, until densities increased in May 1988 to 10 $( \pm 3.0)$ ind $0.05 \mathrm{~m}^{-2}$ and reached maximum densities during September 1988 of $56( \pm 23)$ ind. $0.05 \mathrm{~m}^{-2}$. At the San Francisco station a total of 5 specimens were collected in all samples between July 1987 and September 1988. No specimens were collected at the San Leandro station (Fig. 2) as of November 1988.

In July and August 1988 USFWS surveys recorded $P$. amurensis in several shallow subtidal sloughs and creeks in the South Bay, including (Fig. 2) Steinberger Slough, Plummer Creek (where none was found in 1986), Mowry Slough, and Coyote Creek (Lonzarich \& Hobson 1988).

\section{MECHANISM AND TIMING OF INTRODUCTION OF POTAMOCORBULA AMURENSIS}

\section{Mechanism of dispersal}

The non-teleplanic (oceanic, long-distance dispersing) larvae of potamocorbulids (Wei \& Guan 1985b), 

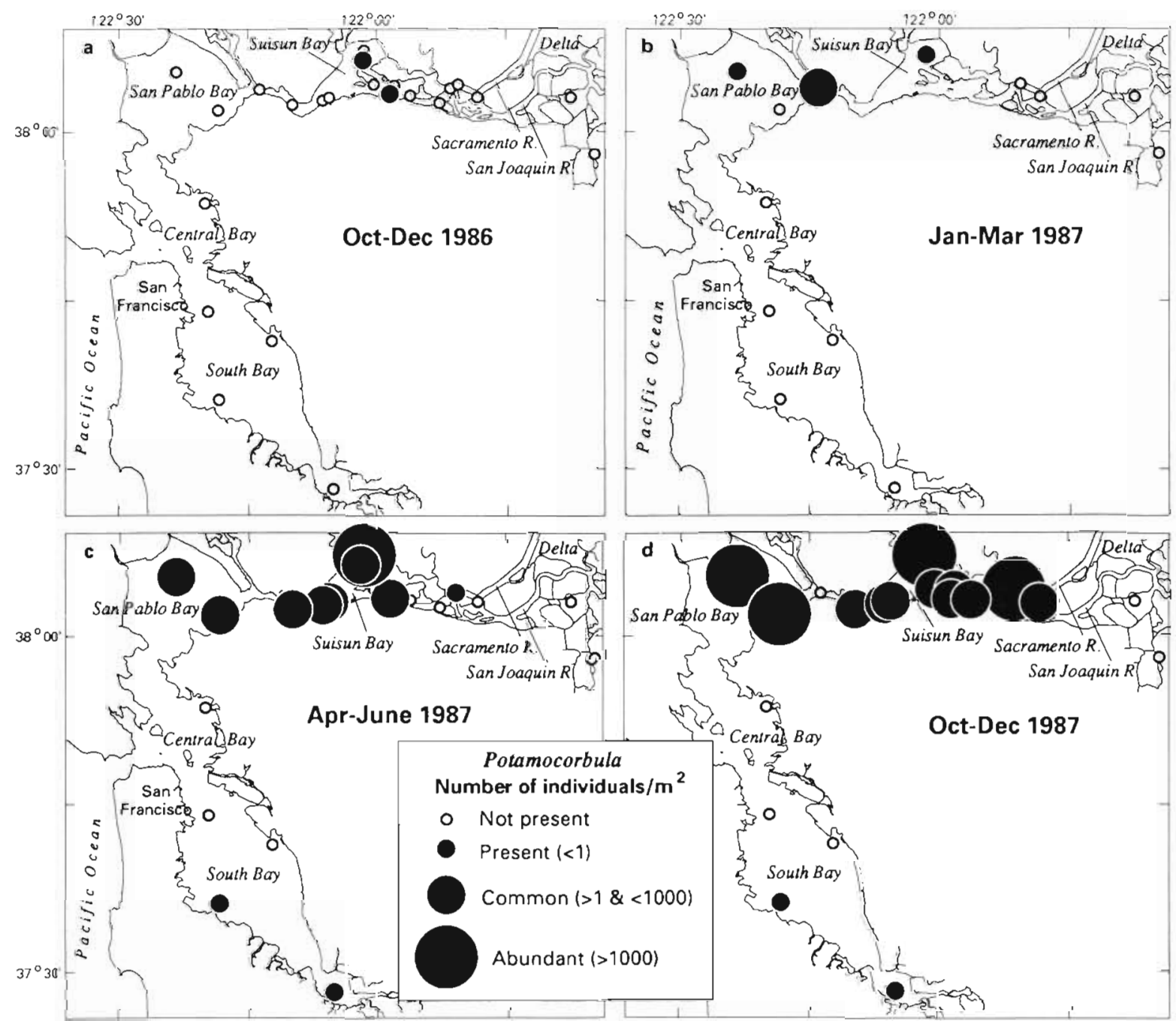

Oct-Dec 1987

Fig. 3. Potamocorbula amurensis. Distribution and relative abundances in San Francisco Bay, October 1986 to December 1987. Abundance data are based upon maximum abundance found at each station during each quarter shown. Note in (b) that DVC (see Table 1) did not sample during this period

and the absence of this clam from intermediate localities between northern Japan and California, preclude its natural transport to the Pacific coast of North Anerica. The arrival of Potamocorbula amurensis in San Francisco Bay appears to be related to extensive shipping activity that provides a unique 'biotic corridor' between Asia and California.

Hundreds of cargo vessels arrive each year in San Francisco Bay from Asian ports. A large number of these vessels are bulk carriers bound for the upriver ports of Sacramento and Stockton to take on grain and wood products ( $T$. Hunter, Operations Manager, Maritime Exchange, San Francisco, pers. comm. 1989). Many of these cargo vessels arrive with thousands of tons of ballast water (not bilge water) taken up in the home port, harbor, or estuary to achieve the necessary trim and stability for the ocean voyage. Depending upon a particular vessel's cargo-loading requirements, ballast water may be released entirely at dockside, or slowly as the vessel moves through San Francisco Bay into the Sacramento or San Joaquin Rivers.

Post-transport ballast water contains high densities and large numbers of species of both holoplankton and meroplankton (Carlton 1985, Williams et al. 1988). Living bivalve veliger larvae at densities exceeding 200 $\mathrm{m}^{-3}$ have been collected regularly by JTC from the ballast water of Japanese cargo vessels arriving in Coos Bay, Oregon, USA. Post-transport viability and competence to settle have been demonstrated by the successful rearing of these larvae to juvenile or adult stages; species raised include Mytilus 'edulis', Trapezium liratum, and Theora lubrica ( = T. fragilis [see Table 3]). One vessel could thus discharge tens of millions of viable veligers into San Francisco Bay. Seawater bal- 


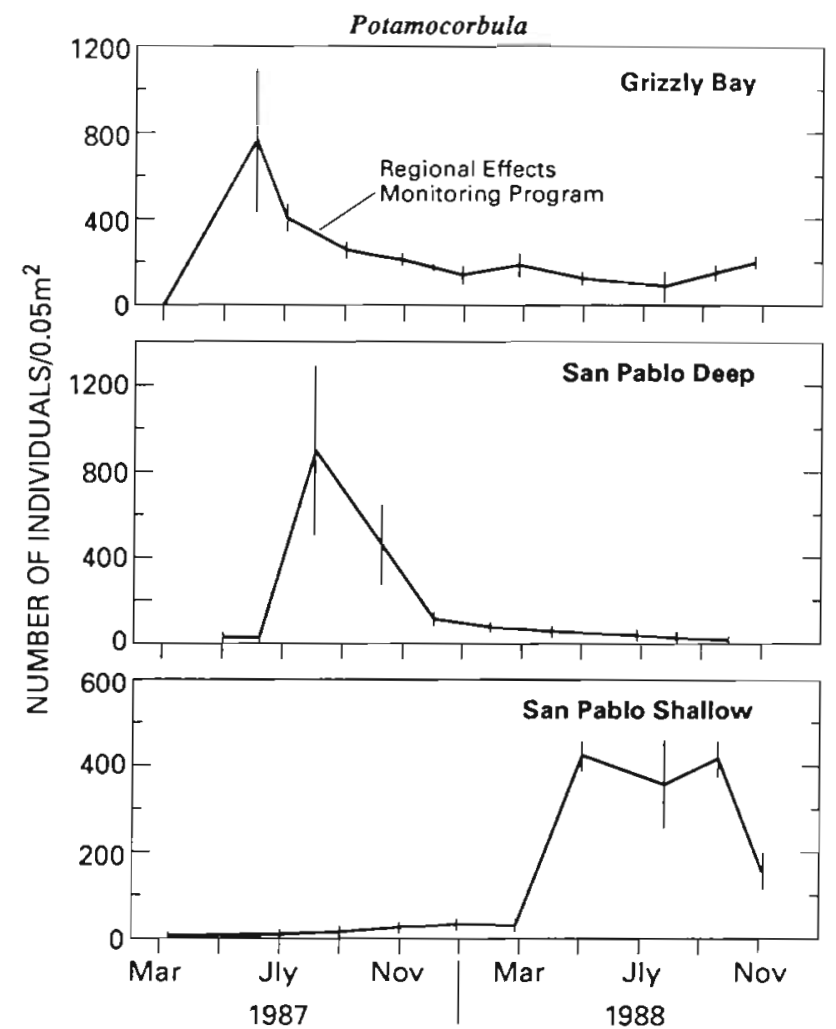

Fig. 4. Potamocorbula amurensis. Densities at 3 North Bay REM stations, March 1987 to November 1988. Means and one standard deviation of five $0.05 \mathrm{~m}^{2}$ replicates are shown

last released in San Francisco Bay and containing the veliger larvae of Potamocorbula amurensis is the most probable mechanism of introduction of this Western Pacific species to the Eastern Pacific Ocean.

The infaunal habitat of Potamocorbula amurensis suggests that it did not arrive as a fouling organism on ship bottoms. $P$. amurensis is not known to be a part of the commercial aquarium or fisheries products trades that each year currently import into California a large number of living invertebrates and fish from Asia.

\section{Timing of introduction}

The first specimens of Potamocorbula amurensis were collected in 1986, but the date of introduction may be difficult to establish with certainty. It is possible that this clam was introduced at a considerably earlier date, and underwent an initially slow population expansion as it established reproducing populations. Environmental conditions in the bay during late 1986 and 1987 - persistently low river inflow and concomitantly elevated salinities (as discussed below) - may have contributed to its remarkable population explosion and, thus, to its discovery.

Four lines of evidence suggest, however, that this clam was probably introduced to the Bay in the mid1980 s. That is, the date of its arrival was relatively close to the time of its discovery. First, biological surveys of the region have been carried out over many years. The earliest thorough faunal surveys occurred in 1911-1912, with expanded effort since the early 1960s (Nichols 1973) and particularly since the mid 1970s (Nichols \& Thompson 1985b). A few or single individuals of many uncommon or rare species were collected in these surveys, but not corbulid bivalves. Second, Potamocorbula amurensis was not in previous samples, taken in 1986, from the same sites where it was first collected and now occurs. Third, all specimens of $P$. amurensis collected prior to March 1987 were less than $11 \mathrm{~mm}$ in length. Age-size relationships of a

Table 2. Regional Effects Monitoring (REM program stations (see Fig. 2, and text; 1980 data [from Dedini et a]. 1982] are shown for selected stations for comparison to non-drought years)

\begin{tabular}{|c|c|c|c|c|c|}
\hline \multirow[t]{2}{*}{ Station no. } & \multirow[t]{2}{*}{ Name } & \multirow{2}{*}{$\begin{array}{c}\text { Depth }(\mathrm{m}) \\
\text { (at mean lower } \\
\text { low water) }\end{array}$} & & \multicolumn{2}{|c|}{$\begin{array}{c}\text { June 1987-November } 1988 \\
\text { Range of: }\end{array}$} \\
\hline & & & & Salinity & Temperature \\
\hline \multicolumn{6}{|l|}{ South Bay } \\
\hline \multirow[t]{2}{*}{1} & Palo Alto & 0 & \multirow{4}{*}{ 1980: } & $24.1-29.5$ & $9.5-25.1$ \\
\hline & Palo Alto & 0 & & $9.6-28.2$ & $10.5-22.9$ \\
\hline 4 & Coyote Point & 2.7 & & $28.3-32.6$ & $9.5-21.6$ \\
\hline 5 & San Francisco & 8.2 & & $28.3-32.6$ & $9.4-20.5$ \\
\hline \multicolumn{6}{|l|}{ Central Bay } \\
\hline 8 & Berkeley & 2.1 & & $29.6-31.9$ & $10.1-18.5$ \\
\hline \multicolumn{6}{|l|}{ North Bay } \\
\hline 10 & San Pablo Shallow (Rodeo) & 1.7 & & $19.2-28.1$ & $8.6-21.0$ \\
\hline 11 & San Pablo Deep & 7.3 & & $24.6-28.9$ & $9.6-19.2$ \\
\hline \multirow[t]{2}{*}{13} & Grizzly Bay & 1.5 & & $4.1-12.5$ & $8.0-20.8$ \\
\hline & Grizzly Bay & 1.5 & 1980: & $0.0-7.6$ & $9.2-21.1$ \\
\hline
\end{tabular}


densities in the lower intertidal zone at Martinez (Fig. 2), where it co-occurs with both Macoma balthica and Mya arenaria. $P$. amurensis was found in small numbers on a sandy mudflat at Rodeo (D. Lonzarich, USFWS, pers. comm. 1988). Regular quantitative sampling of intertidal habitats in San Francisco Bay in the 1980s has not been as extensive as subtidal sampling, and thus $P$. amurensis may be more common at such sites than current data indicate.

The periostracum of Potamocorbula amurensis is worn away or considerably reduced on the lower onehalf to two-thirds of many shells, perhaps reflecting the clam's burial depth and repeated vertical movements at the sediment-water interface. In the laboratory it exposes one-half to two-thirds of its shell above the sediment surface (in both non-flowing [but aerated] and flowing [flume surface water velocities up to $26 \mathrm{~cm}$ $\mathrm{s}^{-1}$ ] water). This behavior may provide a competitive advantage for exploiting planktonic food, as $P$. amurensis does not extend its short siphons more than about $5 \mathrm{~mm}$ above the sediment-water interface when completely buried. At some brackish sites in San Francisco Bay (such as Carquinez Strait) the posterior edge of the shell serves as a settlement site for the introduced Atlantic barnacle Balanus improvisus, a situation that can occur only if this clam is routinely exposed.

Potamocorbula amurensis is, as the genus name (Greek, potamos, river) suggests, a nearly freshwater to euryhaline clam. It ranges from almost freshwater $(<1 \%)$ at Rio Vista, through the brackish waters of Suisun Bay and Carquinez Strait, to the saline waters of the Central and South bay (32.6\%) (Table 2). Ninetyfive specimens (ranging in size from $5.0 \mathrm{~mm}$ to 22.9 $\mathrm{mm}$ ) removed from $11 \%$ water $\left(21\right.$ to $\left.23^{\circ} \mathrm{C}\right)$ in Carquinez Strait in July 1988 and placed without acclimation into $32 \%$ ( 22 to $25^{\circ} \mathrm{C}$ ) in the laboratory showed no mortality after $30 \mathrm{~d}$. Conversely, of ca 100 specimens (same size range) removed from 15\% water (about $18^{\circ} \mathrm{C}$ ) in Suisun Bay in September 1988 and placed without acclimation into $0.1 \%$ river water (from Rio Vista, on the Sacramento River) in the laboratory, more than half were alive and active after $30 \mathrm{~d}$. Experimental clams in both treatments were fed with phytoplankton cultures.

Potamocorbula amurensis is exposed to a moderately broad temperature range in San Francisco Bay, ranging from $8.0^{\circ} \mathrm{C}$ in the winter on shallow subtidal bottoms to $23.0^{\circ} \mathrm{C}$ in the summer on intertidal mudflats.

\section{Asia}

Few details are available on the distributional ecology of Potamocorbula amurensis in Asia. It ranges from the mouth of the Amur River, at the northern end of the Tartar Straits (Tatarskiy Proliv), Khabarovsk, USSR, to the lower delta of the Zhu (Pearl River), west of Hong Kong, on the South China Sea (Schrenck 1867, Zhuang \& Cai 1983). The latter authors record a southernmost locality for this species at Zhuhai (also known as Chuhoi, Chuhai, and Xiangzhoui). It also occurs in Korea, the Bo Sea, the Yellow Sea and the East China Sea, as well as along the west and east coasts of Japan (Habe 1949, Zhadin 1952, Zhuang \& Cai 1983). P. amurensis thus ranges over 30 degrees of latitude from 22 to $53^{\circ} \mathrm{N}$, encompassing tropical to cold temperate waters.

Schrenck (1867) noted that Potamocorbula amurensis occurred up to the mouth of the Amur River at sites that he believed to be freshwater (with occasional intrusions of brackish water), where it co-occurred with the freshwater gastropods Paludina and Melania. Schrenck did not comment upon the possibility that water column stratification near river mouths could allow $P$. amurensis to exist at such sites in saline water at the bottom. Schrenk noted that specimens from 'freshwater' were somewhat smaller than those in brackish water. Zhadin (1952) noted its occurrence in the 'limans of rivers in eastern Asia', Zhuang \& Cai (1983) record it from the intertidal zone to $10 \mathrm{~m}$ on mud bottoms. Yamamoto (1977) reported $P$. amurensis as a dominant benthic species in brackish Lake Obuchi on the Shimokita Peninsula at the northern end of Honshu, Japan.

No information appears to be available on the reproduction, growth, and feeding of Potamocorbula amurensis. However, some data are available for the similar euryhaline and eurythermal corbulid $P$. laevis from the south coast of the Shan Dong Peninsula in northwest China, on the Yellow Sea (Wei 1984, Wei \& Guan 1985a, b, 1986). This locality is at approximately the same latitude $\left(36^{\circ} \mathrm{N}\right)$ as San Francisco Bay $(37$ to $\left.38^{\circ} \mathrm{N}\right)$. A brief summary of some of Wei \& Guan's findings (published in Chinese) provides a comparative background for an understanding of the biology of brackish-water clams of the genus Potamocorbula.

Gametogenesis in Potamocorbula laevis occurs from mid-September to mid-October (water temperatures ranging from 12 to $23^{\circ} \mathrm{C}$ ). Most individuals are dioecious, with a few individuals being simultaneous hermaphrodites. Fertilized eggs ( $45 \mu \mathrm{m}$ diameter) are shed into the water when temperatures are between 16 and $20^{\circ} \mathrm{C}$. Metamorphosis occurs to the D-shell stage after 20 to $22 \mathrm{~h}$; settlement occurs after 30 to $40 \mathrm{~d}$ at a length of about $370 \mu \mathrm{m}$. P. laevis growth rates are greatest when water temperatures are between 22 and $28^{\circ} \mathrm{C}$, with an average monthly growth of 2.0 to $2.5 \mathrm{~mm}$. Growth rates decline in the fall (October) when water temperatures drop below $17^{\circ} \mathrm{C}$; growth ceases below $11.8^{\circ} \mathrm{C}$. Shell growth is greatest during the first $2 \mathrm{yr}$. 
Growth is also greatest in sediments with 70 to $80 \%$ sand, and slower in soft muds. In brackish water (about $3.7 \%$ ), P. laevis consumes only 3 to $4 \%$ of the phytoplankton consumed at between 14 and $34 \%$ (which, if $P$. amurensis is similar, could explain in part Schrenck's report of smaller specimens in freshwater). One-yr-old $P$. laevis shells average $11.5 \mathrm{~mm}$ in length (range 7.2 to $14.5 \mathrm{~mm}$ ); 2-yr-old shells average $17.3 \mathrm{~mm}$ in length (range 14.9 to $20.3 \mathrm{~mm}$ ); 3-yr-old shells average $20.6 \mathrm{~mm}$ in length (range 17.8 to 21.5 ), while 4 -yr-old shells average $22.4 \mathrm{~mm}$ (largest, $24.5 \mathrm{~mm}$ ). P. amurensis is a larger species, reaching $27.5 \mathrm{~mm}$ in Asia, and thus may average slightly larger sizes for each year class.

One-yr-old Potamocorbula laevis occur in densities up to $10000 \mathrm{~m}^{-2}$, while 2 -yr-old clams occur in densities up to $4000 \mathrm{~m}^{-2}$. One- and 2-yr-old clams represented between 82 and $97 \%$ of the populations at 2 different sites. At one site 4 -yr-old clams made up $2.8 \%$ of the population (17 of 600 individuals); at the other site, no 4 -yx-old individuals were present. Thus it would not be surprising to find similar high density populations of $P$. amurensis in San Francisco Bay.

At such high densities Potamocorbula laevis is commercially harvested for poultry feed, for aquaculture as prawn (shrimp) feed (Wei \& Guan 1985a), and for fertilizer (B. Morton pers. comm. 1988).

\section{POTAMOCORBULA AMURENSIS AS COMPETITOR, DISTURBER, CONSUMER, AND PREY}

The physical, chemical, and biological characteristics of benthic and intertidal communities of San Francisco Bay before the arrival of Potamocorbula amurensis are described in Nichols \& Pamatmat (1988). The successful colonization of the San Francisco Bay benthos by $P$. amurensis suggests that a number of community and ecosystem level changes may now be taking place. While field evidence is still limited and experimental studies have not yet been undertaken, we should expect (1) trophic level effects (direct or indirect interactions with other suspension-feeding and deposit-feeding infauna, and alteration of phytoplankton standing stock) and (2) benthic dynamic effects (differential inhibition/enhancement of infauna due to substrate destabilization, changes of suspended sediment loads in bottom water layers, and change of redox balance of the sediment surface). We comment briefly upon each of these here.

\section{Trophic level effects}

Potamocorbula amurensis co-occurs commonly (but at widely varying densities) in San Francisco Bay with the Japanese mussel Musculista senhousia, the Japanese cockle Tapes japonica, the Atlantic soft-shell clam Mya arenaria, and the tellinid clam Macoma 'balthica' (now considered a probable introduction from the Atlantic [Meehan et al. 1989]). Where P. amurensis densities are high in Suisun and San Pablo Bays, $M$. senhousia, $M$. balthica and $M$. arenaria, formerly more abundant, are now rare (Nichols et al. 1990), but a causal relationship to this inverse abundance remains to be experimentally demonstrated. P. amurensis also occurs with the introduced Chinese clam Corbicula fluminea at Point Sacramento and Sherman Lake. It thus joins a host of already established introduced Asian and North Atlantic bivalves in San Franciso Bay with which it may compete both for trophic and spatial resources.

Potamocorbula amurensis occurs with a similar guild of bivalves in Japan. Yamamoto (1977) found $P$. amurensis co-occuring with Musculista senhousia, Macoma takahokoensis (a probable synonym of $M$. balthica [Coan 1971]) and Laternula Limicola in the brackish Lake Obuchi, Japan. L. limicola has been transported to Oregon on the Pacific coast of North America (Keen 1969).

Potamocorbula amurensis consumes diatoms from the water column and those drifting at the watersediment interface. Feces of specimens collected in July 1988 from Carquinez Strait contained the benthic Navicula spp. and the planktonic Coscinodiscus spp. and Skeletonema costatum. The latter are two of the predominant planktonic diatoms of San Pablo and Suisun Bays (Cloern et al. 1985). Wei \& Guan (1985a) reported 25 diatom species from the stomach contents of $P$. laevis from the Qing Long River in northwestern China. These diatoms ranged in size from 25 to $450 \mu \mathrm{m}$ in length and 6 to $60 \mu \mathrm{m}$ in width, whereas diatoms of lesser and greater sizes occurred in the river, leading Wei \& Guan to suggest that $P$. laevis may be capable of food size selectivity. Given its present (1988) population sizes and continuing spread, Potamocorbula amurensis joins the other introduced bivalves $M y a$ arenaria (Nichols 1985), Musculista senhousia, Gemma gemma, and Tapes japonica (Cloern 1982) as a species potentially critically important to phytoplankton dynamics in San Francisco Bay. Further, there is laboratory evidence (W. Kimmerer pers. comm. 1989) that $P$. amurensis actively consumes nauplii of the copepod Eurytemora affinis, a species that is dominant in San Francisco Bay. It is likely that this clam also consumes other holoplanktonic and meroplanktonic invertebrate species. Thus, $P$. amurensis clearly represents a major link in the benthic-pelagic coupling of the San Francisco Bay estuary, and will play a major role in determining the structure of the plankton community.

In a comparable situation in the Potomac River, 
Maryland, USA, Cohen et al. (1984) correlated a 40 to $60 \%$ decrease in 1980/81 in upriver phytoplankton with a high biomass of the introduced freshwater clam Corbicula fluminea, first found in the Potomac in 1977.

\section{Benthic dynamics effects}

The movements and behavior of Potamocorbula amurensis significantly disturb surface sediment layers to a depth of about $1 \mathrm{~cm}$ in laboratory aquaria. The clams form depressions on the sediment surface, intermixed with grooves or 'tracks' created as they move about. The resulting effect is a highly altered, complex surface. This sediment destabilization may influence the relative abundances of mobile and sedentary infauna. Furthermore, increased bottom roughness leads to greater bottom turbulence and an increased tendency for sediment resuspension. At the same time, however, the clam's filtration of the water removes both diatoms and suspended sediment and may have a clearing effect. The clam's bioturbation may further alter the potential redox balance at surface and nearsurface sediment layers.

\section{Potamocorbula amurensis as prey}

Potamocorbula amurensis may become an important prey item for benthic predators such as fish and diving birds. A survey of food items consumed by diving ducks in Suisun Bay and San Pablo Bay, conducted between October 1987 and February 1988, revealed the presence of $P$. amurensis (in addition to the bivalves Tapes japonica, Musculista senhousia, Corbicula fluminea and Mya arenaria) in the stomachs of greater scaups Aythya marila, lesser scaups $A$. affinis and surf scoters Melanitta perspicillata. No $P$. amurensis were in duck diets in a survey conducted from October 1986 to February 1987 at the same sites (P. Hofmann, California Department of Fish and Game, pers. comm. 1988).

Potamocorbula amurensis is also consumed by crabs. Of $85 \mathrm{P}$. amurensis ranging in size from 5.0 to $22.9 \mathrm{~mm}$ randomly chosen from a sample in Carquinez Strait in July 1988, 28 (33\%) bore repaired breaks in their shells identical to those made by predatory crabs. Young Dungeness crabs Cancer magister are abundant at this site (Tasto 1983), and this crab is known to consume small clams in large numbers (Tasto 1983, Asson-Batres 1986). Of the 28 clams that had been attacked, and escaped predation, 27 (96.4\%) had breaks only on their right valves. The larger and more inflated right valve may present a better handling surface to the predator.

\section{CONCLUSIONS}

The establishment of the Asian estuarine clam Potamocorbula amurensis in San Francisco Bay fits into a growing pattern of invasions and colonization of North American Pacific coast harbors and estuaries by Western Pacific species (invasion 'route 12' of Carlton 1987). Fifteen species of western and southwestern Pacific invertebrates and algae have been found in San Francisco Bay in the past 15 yr (Table 3), adding to the more than 20 other Pacific Rim invertebrates, fish, and algae known from the bay prior to 1973 (Carlton 1979. 1985). Two additional Asian gammarid amphipods have been collected in the bay in the past 2 yr (J. Chapman, W. Fields, A. Navarret pers. comms. 1988). Thus, about one new introduced species has been added to the Bay's fauna each year. Quantitative data on the year-by-year establishment and spread of these exotic species are, for the most part, absent. While Newman (1963) noted that the population of the Asian shrimp Palaemon macrodactylus 'virtually exploded' following its first collection in 1957 in San Francisco Bay, and while Brittan et al. (1970) refer to the 'explosive spread' of the Asian goby Acanthogobius flavimanus in the Bay following its discovery in 1963, no surveys were in place nor undertaken to quantitatively and systematically document these apparent patterns. P. amurensis provides us with the first opportunity in the history of faunal invasions in San Francisco Bay to quantitatively document the establishment and spread of an introduced species.

It is probable that far more species - such as polychaetes, turbellarian flatworms, bryozoans, hydroids, small crustaceans, and algae - from Japan, China, and other Asian, southern Asian, and Australasian ports, have been transported and introduced to San Francisco Bay than have been reported; many of these probably remain undiscovered, unidentified, or misidentified as native species. The import rate of new introduced species to San Francisco Bay may thus be considerably greater than our current estimate of one species per year!

Potamocorbula amurensis is ubiquitous with regard to habitat. Within 2 yr of its first collection in the bay it had invaded deltaic, nearly freshwater environments, established itself in creeks and sloughs, on intertidal sand-mud flats, and on subtidal bottoms of a wide range of sediment types. Its increase and spread coincided with an unusually dry period (beginning in mid1986) in California with low river runoff. Salinity data in Grizzly Bay (Table 2) show that waters remained brackish at this site during the winters of 1987 and 1988 , in contrast to a typical winter (e.g. 1980) when this region is inundated with freshwater. Similarly, local river runoff at Palo Alto was minimal in 1987 and 
1988, in contrast to the situation in 1980 (Table 2). Nichols et al. (1990) further consider the window of opportunity that this long dry period may have provided for the successful colonization of San Francisco Bay by P. amurensis. Newman (1963) noted the correlation between the appearance and spread in the Delta region of the Asian shrimp Palaemon macrodactylus (established earlier in San Pablo Bay) during the drought years of 1960 and 1961

While normal winter conditions of high river runoff and low salinities may affect the distribution of Potamocorbula amurensis, its broad habitat and latitudinal range in Asia (in temperatures ranging from $0^{\circ} \mathrm{C}$ to at least $28^{\circ} \mathrm{C}$ [Sverdrup et al. 1947]) suggest that this clam will not be limited by the temperatures or salinities generally found in San Francisco Bay. Benthic communities throughout the Bay, such as those described by Siegfried et al. (1980) (western Sacramento/San Joaquin river estuary), by Nichols \& Thompson (1985a) (south San Francisco Bay), and by many other earlier workers (see Nichols \& Pamatmat 1988 ) have been invaded by $P$. amurensis. We predict that significant changes will occur in these communities as this abundant consumer, competitor, disturber, and prey alters the interactive trophic webs on the floor of San Francisco Bay. Ongoing studies are addressing this issue.

The closely-dated documentation of the first collections, increasing abundance, and spread of Potamocorbula amurensis throughout the bay provide a rare opportunity to observe in progress a biological invasion of an estuary, and to observe community-level alterations as they occur. The introduction of the epifaunal European zebra mussel Dreissena polymorpha into Lake Erie in about 1986 (Hebert et al. 1989) appears to provide a similar and remarkably parallel opportunity in the freshwater Great Lakes. Such documentations provide a foundation for experimental studies to determine the mechanisms by which introduced species may alter and influence community structure.

Acknowledgements. Many individuals contributed to the early resolution and documentation of this major biotic alteration to San Francisco Bay. John Burke (then at DVC) was among the earliest to recognize it as a species new to the bay. We are particularly indebted to Akihiko Matsukuma (National Science Museum, Tokyo), Brian Morton (University of Hong Kong), Terrence Parr and Jay Shrake (Kinnetic Laboratories, Inc. Carlsbad, CA, taxonomic contractors for REM), Paul Scott (Santa Barbara Museum of Natural History) and Michael Kellogg (California Academy of Sciences) for critical taxonomic aid and advice. William Stephenson and his teams of students at Diablo Valley College, Wayne Fields and Susan McCormick (Hydrozoology, Inc., Newcastle, CA, taxonomic contractors for DWR), David Lonzarich (USFWS), and Paul Hofmann and Robert Tasto (CFG) all provided specimens and field data. We thank Harlan Proctor for providing the original unpublished DWR Potamocorbula amurensis data, and
Edward Long for providing the NOAA specimens. James Orsi (CFG), Arleen Navarret (City and County of San Francisco) and John Chapman (Marine Science Center, Newport. Oregon), provided further data on introduced species in San Francisco Bay. At the University of Oregon, Isabel Stirling located the papers of our Chinese colleagues; Wei Deng translated the Chinese for us and kindly answered the same questions several times over Debby Carlton and Theresa Stevens aided with laboratory observations on $P$. amurensis and were fundamental in providing the Japanese ballast water bivalve data referred to in the text. The Oregon ballast water studies were supported by NOAA Sea Grant R/EM-19. We are indebted to Michael Kellogg for Fig. 1 John Chapman, James Cloern, and Mario Pamatmat provided valuable comments on the manuscript.

\section{APPENDIX}

\section{Systematics of Potamocorbula species in the $P$. amurensis-group}

The family Corbulidae is represented in the Eastern Pacific Ocean by ca 20 species in the genus Corbula Bruguière, 1797 (sensu lato) (= Aloidis Megerle van Muhlfeld, 1811). Only one species, Corbula luteola Carpenter, 1864, occurs as far north as Monterey Bay in central California, south of San Francisco (Bernard 1983); the San Francisco Bay corbulids were not this species. The genus Potamocorbula Habe 1955 (subfamily Potamocorbulinae Habe, 1977) contains a number of closely related species in the Western Pacific Ocean (Zhuang \& Cai 1983). No species of Potamocorbula are naturally present in the Eastern Pacific Ocean (Bernard 1983). Corbulid genera and species, particularly in the Indo- and Western Pacific, are in need of extensive revision (B. Morton pers. comm. 1988). Four morphologically similar species within the genus Potamocorbula are (Zhuang \& Cai 1983): P. amurensis (Schrenck 1867), P. laevis (Hinds 1843), P. ustulata (Reeve 1844), and P. rubromuscula Zhuang \& Cai 1983. The 3 former species are placed in the stem genus Corbula by some Western Pacific malacologists. Some Asian and Russian workers use Aloidis since, at one time, Lamarck's 1799 genus Corbula was believed to be an unavailable name, although it was validated by Bruguière in 1797.

San Francisco Bay specimens (Fig. 1) agree with the published descriptions and figures of Potamocorbula amurensis (Schrenck 1867, Zhadin 1952, Zhuang \& Cai 1983). The shells are white, tan, or yellow. There is a prominent external keel ('blunt crest' of Zhadin [1952] and 'umbonal keel' of Schrenck [1867]) on the posterior end of the left valve extending from the umbonal region to the ventroposterior margin. This keel is less pronounced on the right valve, a character noted by Schrenck but not by subsequent authors. Fine radial striae develop on the shell surface in older specimens, 
and the yellow-brown periostracum develops into thick folds along the shell margin, giving an especially wrinkled appearance to the shell surface at the posterior end of the left valve.

The brown siphons of Potamocorbula amurensis are short; the incurrent siphon bears pinnate tentacles, while the nonpinnate excurrent tentacles bear 2 long medial filaments. The entire mantle is fringed with small papillae. $P$. amurensis possesses a correspondingly very shallow pallial sinus. Habe (1949, and repeated in 1955 and 1977 ) illustrated $P$. amurensis without a sinus, in error (A. Matsukuma pers. comm. 1987). A small filamentous byssal-like structure protrudes from the anterioventral end of the mantle cavity of some specimens. The largest specimen collected in San Francisco Bay as of August 1988 was $25.1 \mathrm{~mm}$ in length.

Potamocorbula laevis (which Hinds did not illustrate) is a generally smaller species, reaching, according to Zhuang \& Cai (1983), about $17 \mathrm{~mm}$ in length, as opposed to a maximum length in Asia of $27.5 \mathrm{~mm}$ in P. amurensis. Wei \& Guan (1985a), however, report a maximum length for rare 4 -yr $P$. laevis as $24.5 \mathrm{~mm}$, with 2-yr-old shells averaging $17.8 \mathrm{~mm}$. Schrenck (1867) compared amurensis to Hinds' laevis, noting that the latter was 'shaped more ovally, thereby equilateral, flattened, (and) smooth', characters that are taken directly from Hinds' original description ('an oval shell, equilateral, pale, thin, smooth, flat'). Hinds (1843) further noted that in $P$. laevis 'both valves are flattened toward their ventral margin in a very characteristic manner'. P. laevis lacks the prominent keel on the left shell surface, the fine radial striae in adults, and a pallial sinus (Zhuang \& Cai 1983, whose key, however, uses size as a basis for distinguishing $P$. laevis from $P$. amurensis and $P$. rubromuscula).

Potamocorbula ustulata has a thicker and more triangular shell than either $P$. laevis (thin and oblong) or $P$. amurensis (thin and ovate) (Zhuang \& Cai 1983), although it possesses the keel and pallial sinus of $P$. amurensis. Habe (1977) included $P$. ustulata (resurrected by Zhuang \& Cai) within the synonymy of $P$. amurensis, but he believed the name dated from Reeve (1865), rather than from Reeve (1844), and thus retained the name amurensis as the senior synonym of this species group. If Habe (1977) is correct, and P. ustulata is the same as $P$. amurensis, the former name would have nomenclatural priority.

Potamocorbula rubromuscula is similar in shape to $P$. laevis, but slightly larger; it lacks the strong keel of $P$. amurensis and $P$. ustulata. The presence or absence of a pallial sinus in $P$. rubromuscula is neither mentioned nor illustrated by Zhuang \& Cai (1983). Zhuang \& Cai (1983), using height of the posterior shell margin compared to the anterior margin, distinguish $P$. rubromuscula (posterior higher than anterior) from $P$. amurensis (posterior lower than anterior) in their key (although their text more naturally illustrates $P$. ustulata with $P$. amurensis, and $P$. laevis with $P$. rubromuscula, as species pairs).

\section{Distinctions between Potamocorbula amurensis and other bivalve species in San Francisco Bay}

Potamocorbula amurensis is readily distinguished from other similar appearing clams in San Francisco Bay. Its markedly inequivalve shells distinguish it from the native Cryptomya californica (which also possesses very short siphons) and the introduced Mya arenaria, both in the family Myidae. In $P$. amurensis the smaller and flatter left valve is drawn into the larger and more swollen right valve. Both C. califomica and $M$. arenaria lack the posterior keel. C. californica, reaching a length of about $3 \mathrm{~cm}$, are slightly larger than the adult $P$. amurensis thus far collected in San Francisco Bay. M. arenaria grow to $15 \mathrm{~cm}$.

\section{LITERATURE CITED}

Asson-Batres, M. A. (1986). The feeding behavior of the juvenile Dungeness crab, Cancer magister Dana, on the bivalve, Transennella tantilla (Gould), and a determination of its daily consumption rate. Calif. Fish Game 72: 144-152

Bernard, F. R. (1983). Catalogue of the living Bivalvia of the eastern Pacific Ocean: Bering Strait to Cape Horn. Can. Spec. Publ. Fish. Aquat. Sci. 61: 1-102

Bowman, T E., Bruce, N. L., Standing, J. D. (1981). Recent introduction of the cirolanid isopod crustacean Cirolana arcuata into San Francisco Bay. J. Crustacean Biol. 1: 545-557

Brittan, M. R., Hopkirk, J. D., Conners, J. D., Martin, M. (1970). Explosive spread of the Oriental goby Acanthogobius flavimanus in the San Francisco Bay-Delta region of California. Proc. Calif. Acad. Sci., Series 4, 38: $207-214$

California Department of Water Resources (1987). Water Quality Surveillance Program 1986. Monitoring results pursuant to Delta Water Rights Decision 1485. Volumes I-III. State of California, Sacramento

Carlton, J. T. (1979). Introduced invertebrates of San Francisco Bay. In: Conomos, T J. (ed). San Francisco Bay: the urbanized estuary. Am. Ass. Adv. Sci., Pacif. Div., Calif. Acad. Sci., San Francisco, California, p. 427-444

Carlton, J. T. (1985). Transoceanic and interoceanic dispersal of coastal marine organisms: the biology of ballast water. Oceanogr mar. Biol. A. Rev. 23: 313-371

Carlton, J. T (1987). Patterns of transoceanic marine biological invasions in the Pacific Ocean. Bull. mar. Sci. 41: 452-465

Carlton, J. T (1989). Man's role in changing the face of the ocean: biological invasions and implications for conservation of near-shore environments. Conserv. Biol. 3: 265-273

Carlton, J. T., Scanlon, J. A. (1985). Progression and dispersal of an introduced alga Codium tragile ssp. tomentosoides (Chlorophyta) on the Atlantic coast of North America. Botanica mar 28: 155-165 
Chapman, J. W. (1988). Invasions of the northeast Pacific by Asian and Atlantic gammaridean amphipod crustaceans, including a new species of Corophium. J. Crustacean Biol. 8: $364-382$

Cloern, J. E. (1982). Does the benthos control phytoplankton biomass in South San Francisco Bay? Mar. Ecol. Prog. Ser 9: 191-202

Cloern, J. E., Cole, B. E., Wong, R. L. J., Alpine, A. E. (1985). Temporal dynamics of estuarine phytoplankton: a case study of San Francisco Bay. Hydrobiologia 129: 153-176

Coan, E. (1971). The Northwest American Tellinidae. Veliger 14 (Supl): 1-63

Cohen, R. R. H., Dresler, P. V., Phillips, E. J. P., Cory, R. L. (1984). The effect of the Asiatic clam, Corbicula fluminea, on phytoplankton of the Potomac River, Maryland. Limnol. Oceanogr. 29: 170-180

Dedini, L. A., Schemel, L. E., Tembruell, M. A. (1982). Salinity and temperature measurements in San Francisco Bay waters, 1980. U. S. Geol. Survey Open-File Rept. 82-125: $1-130$

Ferrari, F. D., Orsi, J. (1984). Oithona davisae, new species, and Limnoithona sinensis (Burckhardt, 1912) (Copepoda: Oithonidae) from the Sacramento - San Joaquin estuary, California. J. Crustacean Biol. 4: 106-126

Fleminger, A., Kramer, S. H. (1988). Recent introduction of an Asian estuarine copepod, Pseudodiaptomus marinus (Copepoda: Calanoida), into southern California embayments. Mar Biol. 98: 535-541

Habe, T. (1949). Erodonidae in Japan. Illus. Catl. Jap. Shells, $1 \quad 1-6$

Habe, T. (1955). Notes on Potamocorbula (gen. nov.) amurensis (Schrenck). Zool. Mag., 64: 271-271. (Japanese)

Habe, $T$ (1977). Systematics of Mollusca in Japan. Bivalvia and Scaphopoda. Hoikusha, Osaka

Hebert, P. D. N., Muncaster, B. W., Mackie, G. L. (1989). Ecological and genetic studies on Dreissena polymorpha (Pallas): a new mollusc in the Great Lakes. Can. J. Fish Aquat. Sci. 46: 1587-1591

Hinds, R. B. (1843). Genus Corbula, Bruguière. Proc. zool. Soc. Lond., 11 55-59

Keen, A. M. (1969). Laternula living on the Pacific coast? Veliger 11439

Lonzarich, D., Hobson, K. (1988). A survey of benthic invertebrates of Plummer Creek, South San Francisco Bay. U. S. Fish Widl. Serv. biol. Rept. Contract 11640-00706-86: 1-24

Marelli, D. C. (1981). New records for Caprellidae in California, and notes on a morphological variant of Caprella verrucosa Boeck, 1871. Proc. Biol. Soc. Wash. 94: 654-662

Meehan, B. W., Carlton, J. T., Wenne, R. (1989). Genetic affinities of the bivalve Macoma balthica from the Pacific coast of North America: evidence for recent introduction and historical distribution. Mar. Biol. 102: 235-241

Newman, W. A. (1963). On the introduction of an edible Oriental shrimp (Caridea, Palaemonidae) to San Francisco Bay. Crustaceana 5: 119-132

Nichols, F. H. (1973). A review of benthic faunal surveys in San Francisco Bay. U. S. Geol. Surv. Circ. 677: 1-20

Nichols, F. H. (1985). Increased benthic grazing: an alternative explanation for low phytoplankton biomass in northern San Francisco Bay during the 1976-1977 drought. Estuar coast. Shelf Sci. 21: 379-388

Nichols, F. H., Pamatmat. M. M. (1988). The ecology of the soft-bottom benthos of San Francisco Bay: a community profile. U. S. Fish Wildl. Serv. Biol. Rep. 85 (7.19): 1-73

Nichols, F. H., Thompson, J. K. (1985a). Persistence of an introduced mudflat community in south San Francisco Bay, California. Mar. Ecol. Prog. Ser. 24: 83-97
Nichols, F. H., Thompson, J. K. (1985b). Time scales of change in the San Francisco Bay benthos. Hydrobiologia 129: 121-138

Nichols, F. H., Thompson, J. K., Schemel, L. E. (1990) Remarkable invasion of San Francisco Bay (California, USA) by the Asian clam Potamocorbula amurensis. II. Displacement of a former community. Mar. Ecol. Prog. Ser. 66: 95-101

Orsi, J. J., Bowman, T E., Marelli, D. C., Hutchinson, A (1983). Recent introduction of the planktonic calanoid copepod Sinocalanus doerri (Centropagidae) from mainland China to the Sacramento - San Joaquin estuary of California. J. Plankton Res., 5: 357-375

Powell, A. W B. (1976). On the considerable influx of warm water molluscs that have invaded northern New Zealand waters within recent years. Rec. Auckland Inst. Mus. 13: $141-166$

Rees, J. T. (1982). The hydrozoan Cladonema in California: a possible introduction from East Asia. Pacif. Sci. 36: 439- 444

Reeve, L. A. (1844). Conchologia iconica: or illustrations of the shells of molluscous animals. L. Reeve and Co., London

Reeve, L. A. (1865). Conchologia iconica: or illustrations of the shells of molluscous animals. Reeve and Benham, London

Seapy, R. R. (1974) The introduced semelid bivalve Theora (Endopleura) lubrica in bays of southern California. Veliger 16: 385-387

Schemel, L. E., Ota, A. Y., Harmon, J. G., Shay, J. M., Adorador, R. N., (1988). Benthic macrofauna and ancillary data for San Francisco Bay, California, March to November 1987. U. S. Geol. Survey Open-File Rep., Sacramento, Calif. 88-192: 1-73

Schemel, L. E., Ota, A. Y., Harmon, J. G., Shay, J. M., Adorador, R. N., (1990). Benthic macrofauna and ancillary data for San Francisco Bay, California, January to November 1988. U. S. Geol. Survey Open-File Rep., Sacramento, Calif. 89-596: 1-65

Schrenck, L. v. (1867). Mollusken des Amur-Landes und des Nordjapanischen Meeres. Reisen und Forschungen im Amur-Lande in den Jahren 1854-1856, Vol. 2. Kaiserliche Akademie der Wissenschaften, St. Petersburg, p. 259-974

Siegfried, C. A., Kopache, M. E., Knight, A. W. (1980). The benthos of a portion of the Sacramento river (San Francisco Bay estuary) during a dry year Estuaries 3: 296-307

Sverdrup, H. U., Johnson, M. W., Fleming, R. H. (1947). The oceans. Their physics, chemistry, and general biology. Prentice-Hall, Inc., Englewood Cliffs, New Jersey

Tasto, R. N. (1983). Juvenile Dungeness crab, Cancer magister, studies in the San Francisco Bay area. Calif. Dep. Fish Game Fish Bull. 172: 135-154

Walter, T C. (1986). New and poorly known Indo-Pacific species of Pseudodiaptomus (Copepoda: Calanoida), with a key to the species groups. J. Plankton Res, 8: 129-168

Wei, L. (1984). A preliminary experiment on the artificial rearing of Aloidis laevis (Hinds) and its habits. Mar. Sci. (Qingdao) 6: 32-35 (in Chinese, English abstract)

Wei, L.-P., F.-T Guan (1985a). The growth of Aloidis laevis Chin. J. Zool. 20 (2): 3-7. (Chinese)

Wei, L.-P., F.-T. Guan (1985b). The breeding of Aloidis laevis. Chin. J. Zool. 20 (3): 4-7. (Chinese)

Wei, L.-P., F.-T. Guan (1986). Growing and breeding habits of Potamocorbula laevis. Transactions of the Chinese Society of Malacology, No. 2: 94-101. (Chinese; English abstract)

Williams, R. J., Griffiths, F. B., Van der Wal, E. J., Kelly, J. (1988). Cargo vessel ballast water as a vector for the transport of non-indigenous marine species. Estuar coastal Shelf Sci. 26: 409-420 
Yamamoto, G. (1977). Successional processes observed in the freshening brackish lakes of Shimokita Peninsula J. Fac. mar. Sci. Techn. (Tokai University), 10: $119-128$

Zhadin, V. I. (1952). Mollusks of fresh and brackish waters

This article was submitted to the editor of the USSR. Keys to the Fauna of the USSR, No. 46: $1-368$

Zhuang, Q., Y. Cai (1983). Studies on the Corbulidae (Bivalvia) off Chinese coasts. Trans. Chinese Soc. Malacology, No. 1: 57-68 (Chinese, English abstract)

Manuscript first received: December 13, 1989 Revised version accepted: June 1, 1990 